\title{
DYNAMICS OF SOCIO-POLITICAL DEVELOPMENT OF MODERN UKRAINE IN THE CONTEXT OF PRIORITIES OF LIBERAL DEMOCRACY
}

\section{Hedikova N. P.}

\section{INTRODUCTION}

A democratic project and basic liberal values and principles were laid as the basis for the establishment of independence and the creation of an independent Ukrainian state with the enactment of the Declaration on State Sovereignty of Ukraine (1990) and the Act of Independence of Ukraine (1991). We have confirmed our choice of the civilization vector of development.

Ukraine have had the challenge of extraordinary complexity: to build state institutions, create conditions for the development of civil society, consolidate society around the national idea, that are able to constantly develop and improve the nature of their actions.

Among the weighty reasons that caused the transformational failure of Ukraine, there is a multidisciplinary policy that hasn't made it possible to clearly define the course of strategic development; distortion of democratic procedures; defamation of the electoral system as the main instrument of rotation of power and the mechanism of formation of representative bodies of power; prolonged internal political instability; lack of interaction between the state and civil society. This led to disorganization, growing distrust of the state from the side of society, the escalation of tension within the country.

The Revolution of Dignity and Ukraine's ratification of the Association Agreement with the EU have become a factor in changing state policy, a vector for the development of Ukrainian statehood and all its system-building institutions and civil society. It's focused on the European component of Western civilization dynamics, taking into account the peculiarities of the mentality, culture, spiritual state of the Ukrainian nation and in general, its own state-building experience. These events contributed to the process of transition of Ukraine to a new phase of civilization development. It based on the basic provisions and priorities of the liberal-democratic model of socio-political system. 
We conclude that significant changes need a scientific political science in the development of the Ukrainian state. It will allow us to predict the prospect for further development, which determines the relevance of the proposed research.

\section{Liberal Democracy as a model of the socio-political structure of the state}

The civilization is caused by the victory of the Western bloc in the Cold War. It has undergone serious changes in the last decades of the twentieth century, that have been manifested in the approval of the unipolar orientation of world development, modernization processes in a number of democratic states, and in post-socialist countries. That changes are oriented towards a Western model of state. One of the leading thinkers of the world, philosopher F. Fukuyama described these changes as the end of ideological confrontation and the victory of the ideas of liberal democracy in his essay "The End of History and the Last Human"1.

Liberal democracy was formed in the process of synthesis of liberalism and democracy. Proceeding from the fact that we consider it appropriate first of all to turn to the definition of their essential characteristics and consideration of the criteria for their relationship and interaction. This will enable us to identify the essential characteristics and priorities of modern liberal democracy.

Focusing on the democratic project of institutionalizing the structure and dynamics of the development of political systems, we must realize that liberalism is a historical and philosophical trend, a doctrine and a political ideology. It justifies programmatic arrangements. So, a mass organized movement (liberal political parties, movements, groups etc.), as well as civilization model of public welfare. Democracy isn't ideology, but it's the form of government, the model of state and society, which involves the formation of the necessary conditions to ensure a decent human existence.

Obviously, on the one hand, democracy is intended to ensure the implementation of liberal values. It requires the creation of representative parliamentary democracy and the administration of the state on the basis

${ }^{1}$ Фукуяма Ф. Конец истории и последний человек [пер. с. англ. М. Б. Левина]. Москва: АСТ. 2014. 592 с. 
of the constitution. On the other hand, it needs to be liberalized due to the fact that democracy in its pure form is capable of reaching extreme manifestation. The result of their rapprochement and interaction is liberal democracy. G. Ruggiero says: "Where the adjective is "liberal", it has limitations and serves as an emphasis on the need for detail and differentiation, which is felt in the oppressive and devoid of vital energy of the monotony of a democratic society"2.

There is the main difference between the two political doctrines under consideration. Political liberalism is predominantly oriented on legal norms, the priority of the individual in relation to the collective and the state. Democracy is based on the free expression of the will of the people, or the majority of the opinion in determining the political, economic, social and cultural nature of the system, on the general right of all citizens to a part of political power. In this case, the common will and will of each citizen must coincide in a democratic state. Accordingly, the majority board should be consistent with the provision of individual human rights, which determines the procedures for protection and the mechanism for the exercise of minority rights.

Human as a social element is seen as an autonomous individual (personality) in liberalism, but in a democratic doctrine as a citizen. These constants determine the sphere and place of manifestation of his activity, the resources that he can dispose of.

The convergence of liberalism and democracy consists in the fact that they consider an individual as a citizen who has the right to participate in the political process, in the exercise of political power, in direct participation in the development and adoption of laws, in the definition of a common policy, in political decision-making through general voting and people's representation. They provide for the existence of norms that determine the legitimate means of coming to power and regulate the actions of the institution of power (including each of its subjects at all levels) from according with the values of the country and the will of the people. Both doctrines based on the fact that it can provide the individual complete independence and autonomy in judgments, expression of will and active participation in the political and socio-cultural processes of social development. The principles and values

2 Руджеро Г. Лібералізм і демократія. Лібералізм: антологія. Упоряд. О. Проценко, В. Лісовий. Київ: Смолоскип, 2002. Х +. С. 1031. 
of liberalism and democracy are reflected and specified in the institutes of civil society. Liberalism and democracy aren't commensurate with permissiveness. They predict that the resolution of emerging disputes and controversies and the adoption of necessary decisions should be carried out by an independent judiciary within the legal framework.

The liberal democratic theory has an important feature. It considers liberalism as an order, which is based on the rules of law and legality. Its ideologists focus on individuals who are given priority in the process of making policy decisions in order to avoid the concentration of power in one instance. In this position, liberal democracy reinforces the importance of the theory of human rights. Social collective is considered as a necessity (taking the value of an instrument), which can guarantee and provide to each individual the protection of his rights and freedom in relations with other individuals by its decisions and actions.

Priority in the hierarchy of values of liberal democracy remains the freedom of the individual, which has its own boundaries. It's defined by law, and commensurate with responsibility. This position finds its rationale that in essence the person is an atomic substance of the social whole, therefore, its actions cannot bear the nature of permissiveness. In contrast to democracy, freedom is interpreted not as active participation in politics, but as the freedom of personal interests of citizens, which is not subject to restrictions and coercion by other social actors and social institutions. It also doesn't depend on political power.

It is indisputable that the source of democratic power is the people. In this regard, we share the opinion of Ukrainian researcher M. Sazonov, who believes that "the "people" of liberal democracy have other dimensions, characteristics and ways of realizing the functions of the sovereign power in comparison with the "people" of the classical liberal theory" 3 .

It is argumented by the following evidence. First, M. Sazonov believes that "people" now is much more burdensome than it was one or two centuries ago. Liberal democracy is based on the fundamental principle of "people - the supreme sovereign". It overcomes the restrictions of Western democracies in the nineteenth century, and in

${ }^{3}$ Сазонов М. Ліберальна демократія - модель державного устрою країн Заходу. Порівняльна політика. Основні політичні системи сучасного світу. За заг. ред. В. Бакірова, М. Сазонова. Харків: ХНУ імені В. Н. Каразіна. С. 95. 
some cases, in the middle of the twentieth century. The property, demographic and other qualifications were stored, without which a person did not have the right to vote, and also dispersed the narrow framework of the "people".

Secondly, the author observes that electoral systems in force in Western democracies are contributed to a more complete and effective implementation by the people of their function as the supreme power bearer. These systems have both similarities and differences due to the prevailing type of political culture of the nation. At the same time, all electoral systems in a democratic society should correspond to the history of the country and its traditions. An obligatory requirement for electoral systems is to be "transparent" and to place confidence in the ability to check the results.

Thirdly, liberal democracy has acquired the qualities that allow it to more fully and effectively influence the power. Today, he not only differs from the people of ancient democracies and modern totalitarian states, but also in many ways specific to the "people" of Western democracies, which he had in their classical liberalism. Therefore, M. Sazonov makes the conclusion. On the one hand, it is a people whose diverse interests are recognized as lawful. In fact, their human nature is realized. This is the basis of pluralism, which is a "living soul" of a liberal-democratic system. On the other hand, it is a people who are a complex structure, which is not just the sum of individuals with diverse interests, a number of socio-demographic communities and three or four generations, but also many social strata, whose interests articulate and protect political parties, corporate associations, social movements, interest groups, as well as various social and civic organizations ${ }^{4}$.

Unlike democracy, liberal democracy defends the recognition and observance of minority rights and their institutionalization. As a method of exercising power, it does not crush the minority, as opposed to democratic rule (which in turn does not preclude the guarantee of minority rights), but it allows to realize its interests. Thus, minority is the main determinant and driving force of the political process. It's satisfied the interests of the whole society. This is based on this principle, liberal

${ }^{4}$ Сазонов М. Ліберальна демократія - модель державного устрою країн Заходу. Порівняльна політика. Основні політичні системи сучасного світу. За заг. ред. В. Бакірова, М. Сазонова. Харків: ХНУ імені В. Н. Каразіна. С. 95-98. 
democracy provides a process for their implementation, mainly due to the priority of the interests of the individual and society over the interests of the state. The state is a guarantor of stability and the dynamic development of society. It ensures adherence to the rule of law, principles of social justice, is a controlling and protective social institution.

In turn, society in liberal democracy is seen as an open system in which each individual. It has the right to integrate into different base groups, who can adequately present his concept of the political truth of the goals and on equal grounds to fight for their implementation. This approach suggests that liberal democracy is based on pluralism. In this context, M. Sazonov says that "... the group acts as the main driver of politics. Interested groups are a central element of a modern democratic system that guarantees the realization of interests, human rights and freedoms. The logic is that an individual without a group lacks abstraction. A person is formed only in the group and intergroup relations. The interests, values, motives of behavior and political activity are crystallized. A person gets an opportunity to identify and protect his interests as a part of a group",5.

Liberal democracy plays a decisive role in the question of the progress and effectiveness of society development, giving a market and individualistic orientation in the economy. The fundamental foundation for the successful development of liberal democracies is private property and competition as a means of ensuring equal opportunities and a method of excluding the monopolization of public resources. Liberal democracy appeals to a liberal approach, according to which a society of equal opportunities. It is based on the principles of social justice (equality of rights, which is comparable to responsibility, and equality of starting opportunities) and social solidarity of all its citizens.

Also, the main priorities of liberal democracy are guaranteeing the constitutional rights and freedoms of human and citizen, a developed system of justice, the presence of a broad middle class, freedom of speech and the media, and so on.

The interaction between democratic, liberal and liberal-democratic values are always balanced in democratically-formed political systems.

${ }^{5}$ Сазонов М. Ліберальна демократія - модель державного устрою країн Заходу. Порівняльна політика. Основні політичні системи сучасного світу. За заг. ред. В. Бакірова, М. Сазонова. Харків: ХНУ імені В. Н. Каразіна. С. 98. 
These models are the provision and development of a comprehensive spectrum of human rights and freedoms, the rule of law, popular sovereignty through representative government, the inviolability of the distribution of functions of the legislative, executive and judicial branches of power, the priority of individual interests, civil society over the interests of the state. The priority is the right, freedom, equality among the wide range of value systems in each of them.

The highest social values of the rule of law are human and the rule of law. It should be emphasized that the latter is a derivative of the first, due to the fact that the right is a mechanism for ensuring decent life and human development. Proceeding from the principle of primacy and the rule of law, all its subjects (individual, state, civil society, institutions of power, nation, national minorities, etc.) are subject to him. This principle establishes the beginning and end (that is, sets boundaries) of the legal entities, which oblige them to behave in accordance with legislative and regulatory provisions; legally rationally and reasonably restricts the independence of the state, civil society and its institutions, as well as human freedom. These limits form the basis of constitutional provisions.

Human rights are a valuable standard that provides individuals with free development and self-determination in equal conditions. They have equal opportunities to participate in the selection and formation of a vector of social and state development, an integral element of social relations and the existence of personality.

These models advocate the concept of basic value, which is the freedom of the individual (personal/individual freedom). That determine its significance and the need to liberate a person from all forms of oppression by social institutions. Personal freedom refers to civil liberties - the fundamental rights underlying which are natural law. Civil liberty is a guaranteed opportunity for the law to enjoy the fundamental rights of a person and a citizen, whose recognition and safeguarding of a legal state must be built.

Political freedom means free political will in complying with the laws, as well as the right of every citizen to participate in the management of the state and social structures through democratic procedures, advocate for radical reforms, freely express their views and try to convince them of other people. At the same time, political freedom is seen as an addition to civil liberty as its guarantee. 
The key to spiritual freedom is freedom of speech, conscience, the right to free choice of beliefs and beliefs, free scientific creativity, research, philosophical freedom, freedom of love, sexual freedom, etc. Spiritual freedom is directed to the internal self-management of man, independent, independent development and spiritual perfection.

Material freedom is the improvement of relations that arise in the process of production and distribution of goods. This is a guarantee of the independence of the individual from the collective and social life, and the condition necessary for normal, natural existence. The true sense of freedom is largely determined by the respective economic and material capabilities of each.

All kinds of freedom are in legal mediation, that is, they accept the legal form of expression of freedom, which is realized within the limits of the general moral principles permitted and established by the normative and legislative acts created to protect the interests of man and the state. The theory of "freedom from" and "freedom to" is justified by classical liberalism with classical legal thought. It has already foreseen and pointed to the inevitability (as a natural law of development) of formal legal equality and certain types of inequality (educational, social, economic, etc.). And they did not lose their significance in the process of evolution of civilization, but only switched to a new, more complex state, thus becoming the most important factor in socio-legal relations.

Equality is not an abstract, but a formal one in the models under consideration. All people are equal on a personal level. They advocate a position that people in society may be equal before the law in obtaining civil rights, property rights, etc., but they cannot be equal in their mental and physical capacities. In this way, they insist that the law should take into account equal individuals, both by origin and by abilities. At the same time, providing equality should not restrict of starting opportunities, legislation the rights of people more capable.

Relying on the idea of the same value of each individual, the category of equality is understood as the equality of initial opportunities. It doesn't inequality in the distribution of profits, equality of rights and opportunities for each member of society, while not ignoring the actual (economic and social) inequality of people. Social justice is understood, on the one hand, as the equality of all citizens before the law, on the other hand, as the equality of individuals in moral, political, legal, economic, national-cultural and other rights. The above-mentioned models of 
achievement of true order in society and the state are seen only on the basis of the rule of law and law.

Consequently, liberal democracy is a model of the socio-political system, the form of government and the social organization of life, in which, based on the rule of law, maximum conditions are created for selfdevelopment and self-realization of the individual.

\section{Specific of socio-political development of modern Ukraine}

The Constitution consolidates Ukraine in the status of a sovereign independent, democratic, social, rule of law, whose policy is aimed at creating conditions conducive to decent living and the free development of man.

Article 3 of the current Constitution of Ukraine says: "Human rights and freedoms and their guarantees determine the content and direction of the state's activities. The state is responsible to a person for his activities. The assertion and guarantee of human rights and freedoms is the main responsibility of the state" 6 .

The main task of the state is to fill the actual content of the personal, political, economic, social and cultural rights and freedoms of human and citizen. It's proclaimed by the Ukrainian legislation, creation of the necessary conditions and guarantees of their provision, construction of mechanisms for their protection and realization.

The main mechanism is the rule of law in the system of ensuring the fundamental rights and freedoms of man and citizen. A prerequisite is the rule of law and order for the existence and operation of this mechanism. In aggregate, these factors form the legal basis of real democracy, concentrate all positive features of legal regulation of state and social relations.

The state of ensuring the rights and freedoms of human and citizen as the object of constitutional and legal regulation in modern Ukraine shows that there are problems with their implementation and protection to date and, alas, there are quite a lot of them. It usually takes place in the context of the rule of law, the rule of law and law and order. It should be noted in this regard the opinion of Ukrainian scholars-lawyers O. Litvak and P. Shumsky. They say that the disregard for the law and ignoring its

${ }^{6}$ Конституція України від 28.06.1996 № 254к/96-ВР. Відомості Верховної Ради України. 1996. № 30. Ст. 141. 
norms was a characteristic feature of contemporary social relations. In this situation, law enforcement and other state bodies gross violations of public order and other facts of lawlessness. The rule of law in the country is negatively affected by the lack of a clear mechanism for the implementation of laws, which irresponsibility and low discipline, creates a favorable environment for the robbery of the state, corruption, bribery, the formation of negative opinion in society and the loss of citizens in law enforcement bodies ${ }^{7}$.

The structural components of a democratic rule of law are institutions of public authority. They are based on the priority of the interests of citizens, through whose effective activity the rights and freedoms of a person can be protected and implemented to the extent necessary, the principles of a liberal democratic model of government.

The institute of power in modern Ukraine is structured in accordance with the democratic principle of separation of powers horizontally and vertically, according to a number of parameters, answering liberaldemocratic laws: political pluralism; decentralization; sovereignty and independence of power; elections, referendums and other forms of direct democracy as mechanisms of influence on state policy; consolidation of the political rights and freedoms of citizens in the Constitution.

The principle of distribution of power implies the separation of each of its components as an independent system. It is understood not as a simplified delimitation of competence between different systems of bodies, but as the fulfillment of each of them functions in the field of social life. Their activities are directly related. At the same time, the branches of power balance each other and interact with each other. This key democratic principle is enshrined in Article 19 of the Constitution of Ukraine: "The legal order in Ukraine is based on the principles under which nobody can be compelled to do what is not provided for by law. The bodies of state power and bodies of local self-government, their officials are obliged to act only on the basis, within the limits of authority and in the manner envisaged by the Constitution and laws of Ukraine" ${ }^{8}$. Accordingly, they are managed by the state.

7 Литвак О., Шумський П. Проблеми впровадження Закону України «Про прокуратуру» від 14 жовтня 2014 року. Вісник Нащіональної академї прокуратури України. 2015. № 1(39). С. 5-6.

${ }^{8}$ Конституція України від 28.06.1996 № 254к/96-ВР. Відомості Верховної Ради України. 1996. № 30. Ст. 141. 
Thus, it should be emphasized that within the framework of the Basic Law of Ukraine, the structure of power has received a well-ordered and hierarchical characteristic, although in reality the democratic principle of the division of functions and powers of power is not always respected.

In order to evaluate the activities of state, it is expedient to turn to the definition of the level of trust to them of Ukrainian citizens. Thus, according to the results of a nationwide population survey (which was conducted by the sociological service of the Razumkov Center from 21 to 26 March 2019), 2017 respondents aged 18 and over in all regions of Ukraine took part. The Crimea and the occupied territories of Donetsk and Lugansk regions didn't take part. Ukrainian citizens trust more in volunteer organizations (they are trusted by $68 \%$ of respondents), the Church (61\%), the Armed Forces of Ukraine (61\%), the State Emergency Service (57\%), volunteer battalions (56\%). The institutions of the state, which are more likely to express trust than distrust, also include the State Border Guard Service (it is trusted by 52\% of respondents, 33\% do not trust it), the National Guard of Ukraine (49\% and $35 \%$ respectively), the mass media of Ukraine (respectively $47 \%$ and $41 \%$ ), public organizations (respectively $46 \%$ and 39\%). Nonconfidence is most often expressed by the Verkhovna Rada of Ukraine (82\% do not trust it), the state apparatus (officials) (81\%), the Russian media (79\%), political parties (76\%), the judiciary $(75 \%)$, the Government of Ukraine (74\%), commercial banks (72\%), prosecutors' offices (71\%), the President of Ukraine (69\%), the Specialized AntiCorruption Prosecutor's Office (69\%), the National Anti-Corruption Bureau of Ukraine (NABU) (68\%), the National Agency for the Prevention of Corruption) (68\%), the Supreme Court (67\%), local courts (67\%), the Anti-corruption court (66\%), the Constitutional Court (65\%), the National Bank of Ukraine $(63 \%)^{9}$.

We can conclude of the high level of mistrust of Ukrainian citizens to the institutions of public authority, the judicial and law-enforcement system, and law. It is due to the fact that people were satisfied with the expectations of positive changes after the Revolution of Dignity, but after

9 Рівень довіри до суспільних інститутів та електоральні оріснтації громадян України. URL: http://razumkov.org.ua/napriamky/sotsiologichni-doslidzhennia/rivendoviry-do-suspilnykh-instytutiv-ta-elektoralni-oriientatsii-gromadian-ukrainy-2 
five years from the time of its implementation they haven't met the expectations of building a new type of state in Ukraine.

The essence of state power is the will of the whole society in accordance with liberal-democratic principles. It follows that state power is a unified system consisting of a structural internal organization and an expression of national interests. Bodies of state administration and local self-government aware that the state authorities are not able to take into account the complex diversity of problems and interests of Ukrainian citizens at the regional and local levels and react adequately to them. De-concentration and decentralization power are considered by them one of the main tendencies of political-power relations in modern Ukraine. In this connection, the emergence of a new model of functioning of public power is becoming relevant, which allows creating an institution of real democracy, of which priority is given to local and regional selfgovernment and regional and municipal governance.

Being a connecting link between the state and civil society, the structures of local and regional self-government give the priority to a sovereign individual, protecting its freedoms, rights and interests, essentially designed to bring power (as a mechanism of governance) to the people, to give communities the opportunity freely and responsibly solve the tasks facing them. In turn, this involves expanding local autonomy.

There was a need for reform the system of local self-government and the administrative-territorial structure of the state through the implementation of municipal reform in accordance with the emphasis placed in the issues of clear legislative and normative definition of the powers and responsibilities of public authorities, from the beginning of the declared in the current Constitution of Ukraine (1996) and definitively defined in the Law of Ukraine "On Local Self-Government" (1997). With the enactment of these documents certain steps have been taken in the issue of decentralization of power, a radical change in the system of governance and its territorial basis at all levels began to emerge in 2014 with the enactment of the Concept of Reform of Local Self-Government and Territorial Organization of Power in Ukraine.

There are the transfer of powers and finance from the state to local governments as a result of the enactment of the Concept and the introduction of amendments to the Budget and Tax Codes of Ukraine. So, 
"local budgets in recent years have grown by 165.4 billion UAH: from 68.6 billion in 2014 to 234 billion UAH in 2018 "

After the enactment of the Law of Ukraine "On Voluntary Association of Territorial Communities" of 05.02.2015 № 157-VIII, the Government has begun and successfully implemented the first stage and proceeded to the second stage of the reform on the issue of decentralization of power. According to the Press Center of the "Decentralization" initiative, we can say that this law "has allowed us to begin to form a capable base level of local self-government. From 2015 to 2018, 878 united territorial communities (UTC) had been created in Ukraine. These UTC comprise more than 4,000 former local councils. 9 million people live in UTC. Such international inter-municipal consolidation rates are called by the international experts very high. The law also introduced the Higher Education Institute in UTC, representing the interests of rural residents in the community council. There are already 786 elders working in the UTC villages, and almost 1,7 thousand of them are acting as chiefs. In 2018, united communities received in the communal ownership of almost 1.5 million hectares of agricultural land outside the settlements" $"$.

According to the Article 9 of the Law of Ukraine "On voluntary association of territorial communities" the state provides information and educational, organizational, methodological and financial support. Local state goverments provide organizational support and information and educational assistance to the voluntary association of territorial communities and joining the united territorial communities ${ }^{12}$. Thus, "state support for regional development and community infrastructure development has increased in 39 times during the reform period: from 0.5 billion in 2014 to 19.37 billion UAH in 2018.So, more than 10 thousand projects were implemented in regions and communities in 2015-2018"

This data allow us to apologize that the new model of financial support of local budgets has met the expected results underlying the decentralization reform in Ukraine.

\footnotetext{
${ }^{10}$ Об’єднані територіальні громади. Децентралізація. URL: https://decentralization.gov.ua/about

${ }^{11}$ там само.

12 Про добровільне об'єднання територіальних громад. Закону України від 05.02.2015 № 157-VIII. Відомості Верховної Ради. 2015. № 13. Ст. 91.

${ }^{13}$ Об'єднані територіальні громади. Децентралізація. URL: https://decentralization.gov.ua/about
} 
There is a sufficiently wide network of social institutions at present in Ukraine. Evidence of the results of the practical implementation of the state social policy is the indicators of material well-being of the population of Ukraine and a high degree of socioeconomic inequality, social migration, declining health and life expectancy of individuals, demographic factors, quality of education and medical care, the state of culture. We give some indicators which have been provided by the State Statistics Service of Ukraine in the period from 2015 to 2019 . We take into account precisely this period, because we don't take datas from the temporarily occupied territories of the Autonomous Republic of Crimea, Sevastopol and parts temporarily occupied territories in the Donetsk and Luhansk oblasts. In January 1, 2015, the existing population of Ukraine was 42928.9 thousand people, and as of April 1, 2019, it amounted to 42079.5 thousand people. The number of live births as of January 1, 2015 was 411.8 thousand people, and the number of deaths is 594.8, the difference was -183.0 . In 2018, the relevant indicators are: 364,0 ; 574.1 ; -210.1. The migration movement in 2015 amounted to 533278 people, respectively, in $2018-610687$ people $^{14}$. The folding socio-economic situation in the country indicates that in short-term perspective, it is unlikely that we will be able to gain positive dynamics. Ukraine is in a state of hybrid war with an external aggressor and having a temporarily occupied territory. So, it is very difficult to develop priority areas of life.

An equally important criterion is the presentation of mass consciousness about the values of human and civil rights and freedoms for characterizing the current state of socio-political development in Ukraine. Thus, Ukrainian experts say that freedom, justice and dignity continue to remain among the values of Ukrainians. There is the foundation of human rights, they are based on the data of a pollconducted by the I. Kucheriv "Ukrainian Sociology Service" company. According to which, freedom occupies first place (86\% of respondents mentioned it as the main value). The second place is held by justice ( $70 \%)$, the third is security (67\% of respondents). At the same time, security moved from the second to third place in the rating of core

14 Демографічна та соціальна статистика. Державна служба статистики України. URL: http://www.ukrstat.gov.ua/ 
values in two years. This explains the non-acceptance of undemocratic forms of Ukrainian government and various forms of pressure from the state $^{15}$.

Also, the Ukraine's value priorities were influenced by the change in the contemporary Ukrainian society of the common needs and interests that were conditioned by certain spiritual and moral principles. It formed on the basis of a new vision of the world, the rapid development of the latest technologies, the introduction of innovative models of economic development, civilizational choice of development, challenges the latest process of Ukrainian state-building and others.

Experts note that the population's assessment of the human rights situation. It has taken place since EuroMaydan remains pessimistic. Only $4 \%$ believe that the situation in this area has improved. In contrast, 34\% said that the situation was clearly worse, and another $29 \%$ thought that no changes had occurred. The overall assessment of the observance of various human rights varies between 2 and 3 points on a 5-point scale. The armed conflict in the East of Ukraine continues to affect the attitude of the population towards the observance of human rights ${ }^{16}$.

We share the opinion of Ukrainian scientist Y. Tyshchenko, who states that in the conditions of a loss of confidence in almost all state institutions and politicians, the role of civil society in the processes of transformation of society is particularly responsible, and the question of the interaction of power institutions with the public sector becomes stateowned $^{17}$. The events of the Orange Revolution strengthened the idea of citizens that they could influence the process of making political decisions and change the vector of socio-political development of the country. It based on the will of the majority. But political activity was only temporary. The events of recent years have taken place in Ukraine since 2014. They have shown that citizens have become more mobile, politically active and able to independently defend their rights and freedoms. These trends are evidence of the development and

${ }^{15}$ Колишко С., Паращевін М., Яворський В. Що українці знають і думають про права людини: оцінка змін (2016-2018). Резюме дослідження. Під заг. ред. Т. Печончик. Київ. 2018. С. 5.

${ }_{16}^{16}$ Там само. С. 6.

17 Яблонський В. М., Андріученко Т. В., Бекешкіна I. Е. та ін. Громадянське суспільство України: сучасні практики та виклики розвитку: аналіт. доповідь. За заг. ред. О. А. Корнієвського, Ю. А. Тищенко, В. М. Яблонського. Київ: НІСД. 2018. С. 18. 
consolidation of civil society. This is evidenced by data from the poll of the Democratic Initiatives Foundation named after I. Kucheriv. Thus, according to a survey of representatives of Ukrainian non-governmental organizations (NGOs) conducted by the Fund on February 14-17, 2019 ${ }^{18}$. All respondents agree that the Maidan gave a significant impetus to the development of civil society in Ukraine. At the same time, one third of respondents believe that civil society has already taken significant steps in its development. Somewhat smaller part believes that the Maidan has discovered new development opportunities, which under certain conditions may not be realized. According to the respondents, the Maidan intensified the civil activity of people, showed their capabilities and strength, multiplied "social capital" in society and developed selforganization skills.

Also, as a result of an expert survey, it was established that the current level of civil society is considered by the majority of respondents as average in Ukraine. The effectiveness is positively evaluated of the influence of NGOs on solving urgent problems of the state. A quarter of respondents are less optimistic and consider the influence of their organizations to be largely ineffective.

But we see that the majority of respondents consider it insufficient until the Maidan, but they admit that this influence increased significantly after the Revolution of Dignity. Immediately civil society had had the highest level of influence on power after the Revolution in 2014-2015, which slightly decreased over the next few years, but remained significant. Consequently, it should be noted that the development and strengthening of civil society has taken place. It becomes the dominant factor in social progress.

The democratic institutions are created by public organizations and associations, various unions, associations, trade unions. It ensures the legitimacy of the democratic process. Analysis of the dynamics of institutionalization of civil society is based on the data of the State Statistics Service of Ukraine in the period from 2014 to May 1, 2019 ${ }^{19}$. It

18 Чи стала Революція гідності рушієм розвитку громадянського суспільства експертне опитування. Фонд "Демократичні ініціативи» імені Ілька Кучеріва. URL: https://dif.org.ua/article/chi-stala-revolyutsiya-gidnosti-rushiem-rozvitku-gromadyanskogosuspilstva-ekspertne-opituvannya

19 Єдиний державний реєстр підприємств та організацій України. Державна служба статистики Украӥни. URL: http://www.ukrstat.gov.ua/ 
testifies the tendency to slow growth of the number of registered NGOs in Ukraine. On December 1, 2014 it was 75414; on December 1, 2015 it was 69,686; on December 1, 2016 it was 75,478; on December 1, 2017 it was 80112; on December 1, 2018 it was 84199; as of May 1, 2019, it was 86,015 NGOs. The number of other public groups was growing during this period. The main activities are the control over the activity of the authorities, the fight against corruption, the protection of civil rights and freedoms, socially vulnerable groups, as well as the protection of the natural environment.

One of the main factors is an economically stable civil society in the progressive development of a social and legal state, where most of the population is middle class. Experts note that the number of CEP countries in Ukraine is an order of magnitude lower than its number in developed democracies, which is at least $60 \%$.

So, we conclude that there was a positive in the socio-political development of Ukraine in the period of 2014-2019 in the context of the priorities of liberal democracy.

\section{CONCLUSIONS}

Ukraine has set an ambitious target for its development path and already tore its path to the priority principles of a liberal-democratic model of socio-political system since the implementation of the Revolution of Dignity and regulatory consolidation of interaction with the European Union in the format of association. This path is based on the subjectivity of Ukraine. It's the ability of the state to decide independently on the choice of the form and model of its national-state development in accordance with national interests, to take an active part in the formation of international politics, in the processes of globalization, in the formation of a new system of international relations.

New Ukraine is based on the principles of sustainable development, rule of law, protection of human rights, democracy, solidarity, good governance. For the last years of Ukraine's development, it became clear that Ukrainians are quite clearly aware of their own values, determine the priorities of their own country. They are ready to act in defense of their rights, freedoms and democracy.

The irrevocability of change is ensured by active participation of the public. Ukrainian citizens had become an active subject of power and 
legal relations, motivating the choice of methods and means of state governance and the formation of civil society institutions in recent years.

It should be noted that there is still a tangible negative effect of reforms positively evaluating the dynamics of Ukraine's socio-political development during 2014-2019 in the context of the priorities of liberal democracy. The state is now fragmentation of economic reform, slow implementation of judicial reform, reform of state funds, anti-corruption reform in Ukraine.

Incomplete reforms (chaotic and unsystematic mechanisms) is a threat to undermine confidence in public authorities and increase socioeconomic tension in society. The negative trends have emerged in Ukraine. But overcoming it is possible only through the systematic modernization of the whole complex of relations and institutions in the coordinate system of the state - society - a person.

In our opinion, Ukraine is part of the Eastern European culture and civilization community. The European choice of development is based on the priorities of the Western model of liberal democracy. It is undoubtedly justified.

\section{SUMMARY}

This article is considered essential characteristics and criteria of the relationship and interaction of democracy and liberalism. There is determined and analyzed the priorities of modern liberal democracy in comparison with democracy and liberalism. It is argued that liberal democracy as a model of socio-political system, the form of government and the social organization of life based on the rule of law creates the maximum conditions for self-development and selfrealization of the individual. There are analyzed the peculiarities of socio-political development of modern Ukraine in the context of the priorities of the liberal-democratic model. The emphasis is on state institutions, the reform of local self-government and territorial organization of power, the state and capabilities of civil society in Ukraine. The article is offered the author's generalizations and conclusions about comprehension of modern development of Ukraine as a new independent state of Eastern Europe. It's projected the prospect for further development of the Ukrainian state. 


\section{REFERENCES}

1. Фукуяма Ф. Конец истории и последний человек [пер. с. англ. М. Б. Левина]. Москва: АСТ. 2014. 592 с.

2. Руджеро Г. Лібералізм і демократія. Лібералізм: антологія. Упоряд. О. Проценко, В. Лісовий. Київ: Смолоскип, 2002. Х +. C. $1026-1032$.

3. Сазонов М. Ліберальна демократія - модель державного устрою країн Заходу. Порівняльна політика. Основні політичні системи сучасного світу. За заг. ред. В. Бакірова, М. Сазонова. Харків: ХНУ імені В. Н. Каразіна. С. 80-117.

4. Конституція України від 28.06.1996 № 254к/96-ВР. Відомості Верховної Ради Украӥни. 1996. № 30. Ст. 141.

5. Литвак О., Шумський П. Проблеми впровадження Закону України «Про прокуратуру» від 14 жовтня 2014 року. Вісник Національної академї прокуратури Украӥни. 2015. № 1(39). С. 5-10.

6. Рівень довіри до суспільних інститутів та електоральні орієнтації громадян України. URL: http://razumkov.org.ua/napriamky/ sotsiologichni-doslidzhennia/riven-doviry-do-suspilnykh-instytutiv-taelektoralni-oriientatsii-gromadian-ukrainy-2

7. Об'єднані територіальні громади. Децентралізація. URL: https://decentralization.gov.ua/about

8. Про добровільне об'єднання територіальних громад. Закону України від 05.02.2015 № 157-VIII. Відомості Верховної Ради. 2015. № 13. Ст. 91.

9. Демографічна та соціальна статистика. Державна служба статистики Украӥни. URL: http://www.ukrstat.gov.ua/

10. Колишко С., Паращевін М., Яворський В. Що українці знають і думають про права людини: оцінка змін (2016-2018). Резюме дослідження. Під заг. ред. Т. Печончик. Київ. 2018. 96 с.

11. Яблонський В. М., Андріученко Т. В., Бекешкіна I. Е. та ін. Громадянське суспільство України: сучасні практики та виклики розвитку: аналіт. доповідь. За заг. ред. О. А. Корнієвського, Ю. А. Тищенко, В. М. Яблонського. Київ: НІСД. 2018. 128 с.

12. Чи стала Революція гідності рушієм розвитку громадянського суспільства - експертне опитування. Фонд "Демократичні ініціативи» імені Ілька Кучеріва. URL: https://dif.org.ua/article/chi-stala-revolyutsiya-gidnosti-rushiem-rozvitkugromadyanskogo-suspilstva-ekspertne-opituvannya 
13. Сдиний державний реєстр підприємств та організацій України. Державна служба статистики України. URL: http://www.ukrstat.gov.ua/

\section{Information about the author:} Hedikova N. P. $\mathrm{PhD}$ in Political Sciences, Professor, Professor at the Department of Political Science and Law, State Institution «South Ukrainian National Pedagogical University named after K. D. Ushynsky» 26, Staroportofrankivska str., Odesa, 65020, Ukraine 